\title{
Knowledge about emergency management of dental trauma among school teachers of Bhalktapur Nepal
}

\section{Pradhan $\mathrm{M}^{1}$, Joshi $\mathrm{U}^{2}$, Aryal UR ${ }^{3}$, Upadhyay $\mathrm{S}^{4}$, Shrestha $\mathrm{A}^{5}$}

${ }^{1}$ Megha Pradhan, Lecturer, Department of Pedodontics and Preventive Dentistry, Kathmandu Medical College Teaching Hospital; ${ }^{2}$ Ujjwal Joshi, Lecturer, Department of Oral Medicine and Radiology, KIST Medical College and Teaching Hospital; ${ }^{3}$ Umesh Raj Aryal, Assistant Professor, Department of Community Medicine, Kathmandu Medical College Teaching Hospital; ${ }^{4}$ Sumita Upadhyay, Assistant Professor, Department of Pedodontics and Preventive Dentistry, Kathmandu University School of Medical Sciences, Dhulikhel; ${ }^{5}$ Amrita Shrestha, Lecturer, Department of Orthodontics, Kathmandu Medical College Teaching Hospital, Kathmandu, Nepal

\begin{abstract}
Background: Injury to a young child's teeth and face is a traumatic experience for the child and parents. Prompt and effective action on traumatized teeth significantly increases the likelihood of a positive treatment outcome. Adequate knowledge of school teachers in emergency situation arising during school hours can prove to be a boon for the child's oral health.

Objectives: To assess the knowledge of school teachers of Bhaktapur about emergency management of dental trauma and also to measure the relationship between socio demographic characteristic of teachers and knowledge about dental emergencies.

Methods: The cross sectional study was conducted among 424 schools teachers of Bhaktapur district from September 2014 to March 2015. Simple random sampling was done to select the schools. Questionnaire was distributed among the teachers after taking their informed written consent. Data was collected and sent for statistical evaluation. Frequencies and percentage were calculated. Chi-square and Fisher's Exact test were applied.

Results: Nearly one third (32.2\%) teachers who had information on dental trauma knew the proper management of displaced teeth $(p=0.01)$. Statistically significant difference was found among those who had first aid training and proper management of displaced teeth $(p=0.04)$. Teachers who had experienced dental trauma in their students were only confident of managing displacement of traumatized teeth $(p=0.02)$.

Conclusion: Knowledge of the school teachers in Bhaktapur was seen to be inadequate for emergency management of fracture and avulsed tooth.
\end{abstract}

Key words: Emergency management, School teachers, Teaching experience, Traumatic dental injuries.

\section{INTRODUCTION}

T njury to both, primary and the permanent dentitions Land their supporting structures is one of the most common dental problems seen in children. Dental trauma may exceed dental caries and periodontal disease as the most significant threat to dental health among young people, and is accompanied by significant economic consequences'. Child being in a dynamic state of growth both mentally and physically is more susceptible to fall and injury due to his lack of muscle

Address for correspondence

Dr. Megha Pradhan

Lecturer, Department of Pedodontics and Preventive Dentistry

Kathmandu Medical College Teaching Hospital

Sinamangal, Kathmandu, Nepal

E-mail:drmeghapradhan@gmail.com coordination ${ }^{2}$. Injury to a young child's teeth and face is a traumatic experience for child and parents. In most cases of dental trauma a rapid and appropriate treatment can lessen its impact from both an oral and esthetic standpoint ${ }^{3}$.

Dental trauma can vary from a minor enamel chip to extensive maxillofacial damage involving the supporting structures and displacement or avulsion of teeth ${ }^{4}$. Epidemiological studies of dental trauma have shown that most dental accidents in children occur at home followed by school ${ }^{5-9}$. It was reported that sport and school injuries accounted for $60 \%$ of dental trauma ${ }^{8}$. In the age group 0-6 years, oral injuries are ranked as second most common injury covering $18 \%$ of all somatic injuries. Among the oral injuries, dental injuries are most frequent ${ }^{10-12}$. 
At present there are 31,555 primary, 11,341 lower secondary, 6,298 secondary and 2,512 higher secondary schools which illustrates the uprising education system in Nepal ${ }^{13}$. As provided by the Department of Education, Bhaktapur district consists of 428 schools $^{14}$. Teachers are responsible for maintaining the quality of the school progress. Their effectiveness is the basic component and an important predictor of school effectiveness ${ }^{15}$. Studies have shown that irrespective of first aid training, the knowledge of school teachers towards management of traumatic dental injuries was inadequate $e^{4,16-24}$. The prognosis of traumatized teeth depends upon the correct and prompt treatment which often relies on common people like teachers and parents present at the site of accident ${ }^{4}$.

Data on dental injuries in Nepal is scanty. Knowledge of school teachers in emergency situation arising during school hours can prove to be a boon for the child's oral health. Bhaktapur is one of the densely populated areas with large number of educational institutions. As study evaluating the knowledge of school teachers in Bhaktapur district is not done previously, this study was formatted to assess the knowledge of school teachers of Bhaktapur about emergency management of dental trauma and also to measure the relationship between socio-demographic characteristic of teachers and knowledge about emergency management of dental trauma.

\section{METHODS}

This cross sectional study was conducted among the schools teachers of Bhaktapur district from September 2014 to March 2015. Minimum sample size of 385 respondents was calculated based on unknown prevalence of knowledge about emergency management of school teachers of Bhaktapur. Fifty percent assumed for conservative sample size determination, about precision five percent, 95\% confidence limits. Assuming $10 \%$ non response rate and incomplete questionnaires ${ }^{25}$, we decided to include 424 school teachers as our sample size.

Teachers who were willing to participate with their informed written consent were included in the study. Teachers who were unwilling to participate or on leave were excluded from the study.

Simple random sampling was done to select the schools. Ethical consent was taken from the institutional review committee along with permission from the principal of the respective schools prior to conducting the study.
The questionnaire distributed among the teachers comprised of eight questions assessing their sociodemographic profile and sixteen questions to evaluate their knowledge on emergency management. The pretested semi-structured questionnaire in the previous study ${ }^{4}$ was modified and translated from English to Nepali language by an expert and both the language were incorporated for the ease of the participant. Data from the questionnaire was entered in SPSS version 11 and statistical analysis was done. Frequency and percentage were calculated to assess the level of awareness towards traumatic dental injuries. Chi-square test and Fisher's Exact test were applied to measure relationship between socio-demographic characteristic of teachers and knowledge about emergency dental trauma.

\section{RESULTS}

Among the 424 teachers, one hundred and seventeen (27.6\%) were male and three hundred and seven (72.4\%) were female. Majority of the teachers 325 (76.7\%) were from private schools, with only 99 (23.3\%) from public schools. Three hundred and forty four teachers (81.1\%) worked in those schools providing secondary level of education. Playgrounds were present in the schools where four hundred and twelve teachers (97.2\%) worked. Majority of the teachers 204 (48\%) belonged to 21-30 years of age group and were mostly graduated 271 (63.9\%). The professional profile indicated that only $134(31.6 \%)$ of the teachers had undergone first aid training while 151 (35.8\%) had received information on dental trauma. Information on dental trauma was mostly received from lectures with the dentist by ninety nine teachers (23.4\%).

About 223 (52.6\%) of teachers had confidence on identifying between primary and permanent teeth. With regards to management of tooth avulsion, fourteen teachers $(3.53 \%)$ knew the proper management by locating the tooth and attempting to replant it. Majority of the teachers 277 (65.3\%) were worried about stopping the bleeding with pressure as loss of blood is perceived to be life threatening. In context of replantation of deciduous tooth, two hundred and seventeen teachers (51.4\%) gave the correct answer while one hundred and ninety-eight (46.7\%) were incorrect in context of replanting permanent teeth. On questioning them about where they would take if there is any dental emergency, nearly half $(50.5 \%)$ of teachers preferred nearest hospital on foot or by any transport while only $32.3 \%$ would like to take to a dentist. It was reassuring to know that three hundred and sixty seven (86.6\%) of teachers would send the child immediately in case of emergency. 
Sixty nine (16.3\%) of the participants thought avulsed teeth were useless to save. While thirty $(7.3 \%)$ of them preferred disinfection solution, thirty nine (9.2\%) preferred gauze as their storage media. Distilled water was favored by twenty one (5\%) teachers while still two hundred and twenty five teachers (53.1\%) had no idea about storage media. Thirty four teachers (8.25\%) knew the proper management of fracture teeth by putting the fractured part on liquid medium and taking to the dentist. Eighty nine (21\%) teachers knew about the correct management of displaced teeth.

Two hundred and forty eight (58.7\%) teachers had never heard of mouth guard while 159 (37.7\%) thought it could prevent injury to the tooth. Replantation of avulsed permanent tooth is the ideal mode of treatment .In contrast, three hundred and fifty one teachers (83\%) in our study believed that they didn't think about it as a treatment option. One hundred and eight (25.5\%) of the teachers had the experience of coming across dental trauma in their students and among them, three hundred and twenty six (77.1\%) had in range of (1-5).

Statistically significant difference $(p=0.04)$ was found among those who had first aid training and proper management of displaced teeth (Table 1)

Nearly one third (32.2\%) of teachers who had information on dental trauma knew the proper management of displaced teeth which was statistically significant $(p=0.01)$ as shown in (Table 2$)$.

Among the 108 teachers who had experienced dental trauma in their students for the past one year, thirty one (28.7\%) knew the correct management for displaced teeth where significant association ( $p=0.02$ ) could be found (Table 3).

Statistically significant relation was only found between the teachers' teaching experience and proper management of displaced teeth rather than fracture and avulsion ( $p=0.04)$ (Table 4)

Table 1: Relationship seen between management of dental traumatic injuries and first aid training done

\begin{tabular}{|c|c|c|c|c|c|}
\hline \multirow{2}{*}{ Type of injury } & \multicolumn{4}{|c|}{ First aid training done } & \multirow[b]{2}{*}{ p value* } \\
\hline & & Yes $(n=134)$ & No $(n=290)$ & Total & \\
\hline \multirow{2}{*}{ Avulsion } & Yes & $5(3.7 \%)$ & $10(3.4 \%)$ & $15(3.6 \%)$ & \multirow{2}{*}{$p=0.88$} \\
\hline & No & $129(96.3 \%)$ & $280(96.6 \%)$ & 409 (96.4\%) & \\
\hline \multirow{2}{*}{ Fracture } & Yes & $9(6.7 \%)$ & $26(9 \%)$ & $32(8.3 \%)$ & \multirow{2}{*}{$p=0.43$} \\
\hline & No & $125(93.3 \%)$ & 264 (91\%) & 389 (91.7\%) & \\
\hline \multirow{2}{*}{ Displacement } & Yes & 37 (27.6\%) & $52(17.9 \%)$ & $89(21 \%)$ & \multirow{2}{*}{$p=0.02$} \\
\hline & No & 97 (72.4\%) & $238(82.1 \%)$ & 335 (79\%) & \\
\hline
\end{tabular}

*Fisher's exact test applied

Table 2: Relationship seen between management of dental traumatic injuries and information the teachers have got on dental trauma

\begin{tabular}{lccccc}
\hline & \multicolumn{2}{c}{ Information on dental trauma } \\
Type of injury & & Yes & No & Total & p value* \\
Avulsion & Yes & $8(5.3 \%)$ & $7(2.6 \%)$ & $152(35.8 \%)$ & $p=0.15$ \\
Fracture & No & $144(94.7 \%)$ & $265(97.4 \%)$ & $272(64.2 \%)$ & \\
& Yes & $13(8.6 \%)$ & $22(8.1 \%)$ & $35(8.3 \%)$ & $p=0.868$ \\
Displacement & No & $139(91.4 \%)$ & $250(91.9 \%)$ & $389(91.7 \%)$ & \\
\hline
\end{tabular}

*Fisher's exact test applied 
Table 3: Relationship seen between management of dental traumatic injuries and experience of trauma in their students

\begin{tabular}{|c|c|c|c|c|c|}
\hline \multirow{2}{*}{ Type of injury } & & \multicolumn{4}{|c|}{ Experienced dental trauma in past one year } \\
\hline & & Yes (\%) & No (\%) & Total & p value* \\
\hline \multirow{2}{*}{ Displacement } & Yes & $31(28.7)$ & $58(18.4 \%)$ & $89(21 \%)$ & \multirow{2}{*}{$p=0.02$} \\
\hline & No & $77(71.3)$ & $258(81.6 \%)$ & $335(79 \%)$ & \\
\hline \multirow{2}{*}{ Fracture } & Yes & $6(5.6)$ & $29(9.2 \%)$ & $35(8.3 \%)$ & \multirow{2}{*}{$p=0.23$} \\
\hline & No & $102(94.4)$ & $287(90.8 \%)$ & $389(91.7 \%)$ & \\
\hline \multirow{2}{*}{ Avulsion } & Yes & $4(3.7)$ & $11(3.5 \%)$ & $15(3.6 \%)$ & \multirow{2}{*}{$p=0.9$} \\
\hline & No & $104(96.3)$ & $305(96.5 \%)$ & $409(96.4 \%)$ & \\
\hline
\end{tabular}

*Fisher's exact test applied

Table 4: Relation between teaching experience and the proper management of dental traumatic injuries

\begin{tabular}{|c|c|c|c|c|c|c|}
\hline \multirow{2}{*}{$\begin{array}{l}\text { Age groups } \\
\text { (years) }\end{array}$} & \multicolumn{2}{|c|}{ Avulsion } & \multicolumn{2}{|c|}{ Fracture } & \multicolumn{2}{|c|}{ Displacement } \\
\hline & $\begin{array}{c}\text { Yes } \\
\text { n (\%) }\end{array}$ & $\begin{array}{c}\text { No } \\
\text { n (\%) }\end{array}$ & $\begin{array}{c}\text { Yes } \\
\text { n (\%) }\end{array}$ & $\begin{array}{c}\text { No } \\
\text { n (\%) }\end{array}$ & $\begin{array}{c}\text { Yes } \\
\text { n (\%) }\end{array}$ & $\begin{array}{c}\text { No } \\
\text { n (\%) }\end{array}$ \\
\hline $1-10$ & $6(40.0)$ & $273(66.7)$ & $19(54.3 \%)$ & $260(66.8 \%)$ & 63 (70.8\%) & 216 (64.5\%) \\
\hline$>10-20$ & $6(40.0)$ & $79(19.3)$ & $11(31.4 \%)$ & 74 (19.0\%) & $10(11.2 \%)$ & 75 (22.4\%) \\
\hline$>20-30$ & $2(13.3)$ & $50(12.2)$ & $5(14.3 \%)$ & 47 (12.1\%) & $13(14.6 \%)$ & 39 (11.6\%) \\
\hline$>31-40$ & $1(6.7)$ & $6(1.5)$ & $0(.0 \%)$ & $7(1.8 \%)$ & $2(2.2 \%)$ & $5(1.5 \%)$ \\
\hline$>40$ & $0(0)$ & $1(0.2)$ & $0(0 \%)$ & $1(.3 \%)$ & $1(1.1 \%)$ & 0 ( $0 \%)$ \\
\hline Fisher's Exact & \multicolumn{2}{|c|}{$p=0.07$} & \multicolumn{2}{|c|}{$p=0.36$} & \multicolumn{2}{|c|}{$p=0.04$} \\
\hline
\end{tabular}

\section{DISCUSSION}

Stage of dentition development is an important factor in determining the correct emergency management. When questioned on whether they were able to identify between primary and permanent tooth, $52.6 \%$ of the school teachers were confident they could. Similar findings were seen for permanent teeth by Al-Jundi et $\mathrm{al}^{16}$ and by Chan et $\mathrm{al}{ }^{4}$ which were $40 \%$ and $47 \%$ respectively.

Among the three dental injuries addressed in the study, the teachers were found to be very much confident on managing displaced than avulsed and fractured teeth. Inadequate knowledge of tooth fracture and avulsion management was also seen in study done by Feldens et $\mathrm{a}^{26}$. While Sae-lim et $\mathrm{al}^{19}$, Mohandas $U$ et $\mathrm{a}^{{ }^{21}}$ and Mesgarzadeh et $\mathrm{a}^{27}$ found good knowledge among teachers in managing fracture and avulsion.

Nearly one third (32.2\%) of teachers who had information on dental trauma knew the proper management of displaced teeth which was statistically significant $(p=0.01)$, while the management on fracture and avulsion were insignificant. This gives an assumption that they had received proper knowledge only on managing displaced teeth by their interaction with the dentist.
Thirty five (8.25\%) teachers knew the proper management of fracture teeth by putting the fractured part on liquid medium and taking to the dentist which highlights their inadequate knowledge in this aspect. Similar findings (22.5\%) were noted by Feldens et al ${ }^{26}$ in their study. While Sae-lim et $\mathrm{al}^{19}$, Mohandas et $\mathrm{al}^{21}$, Mesgarzadeh et $\mathrm{al}^{27}$ found a better management of fractured teeth among their participants.

With regards to the emergency management of tooth avulsion, majority of the teachers (65.3\%) were worried about stopping the bleeding with pressure as loss of blood is perceived to be life threatening by most people which was also seen in study by Chan et al ${ }^{4}$ and Mohandas et $\mathrm{a}^{2{ }^{21}}$. The awareness about the proper management of "locating the avulsed tooth and attempting to replant it" was seen only in $3.53 \%$. Similarly grossly deficient knowledge about tooth avulsion was seen by Mohandas et $\mathrm{al}^{21}$, Al Jundi et $\mathrm{al}^{16}$, to be $1.5 \%$ and $1 \%$ respectively. In contrast to our study, adequate knowledge in management of tooth avulsion were reported by Chan et al $(17.5 \%)^{4}$, Sae-lim et al $(71 \%)^{19}$ and Mesgarzadeh et $\mathrm{al}^{27}(50.6 \%)$ although the latter mentioned that teachers were not informed of correct procedures. Replantation of avulsed permanent tooth is the ideal mode of treatment. In contrast, majority of teachers (83\%) in our study believed that they didn't think about it as a 
treatment option. Studies done by C Blakyty et a $\mathrm{a}^{28}$ and Mclntyre et al ${ }^{28}$ showed similar findings as $74.5 \%$ and $44 \%$ respectively. Replanting of avulsed primary teeth has the potential risk of damaging the permanent successor $^{30}$. More than half of the teachers $(51.4 \%)$ did not think of replantation which was reassuring.

The prognosis is related to the injury of the periodontal membrane during the time the tooth is out of its socket. Dry storage of the tooth will result in an irreversible injury to the periodontal membrane, with the result that the replanted tooth will be lost over time. Storage media like saline, milk, balanced salt solution with osmolality similar to the tissue fluid do not destroy the periodontal ligament cells ${ }^{31}$. Majority (53.1\%) didn't have any idea on medium required for storage/transportation of knocked out teeth similar to study done by Mohandas et a ${ }^{21}$ whose finding was $58.3 \%$. Extra oral time less than 20 minutes is considered ideal for replantation of teeth. It was reassuring to know $86.6 \%$ of teachers would send the child immediately in case of dental emergency.

Among the 108 teachers who had experienced dental trauma in their students for the past one year, thirtyone (28.7\%) knew the correct management for displacement where significant association could be found. Similarly, Sea-Lim et $a{ }^{19}$ stated that $24 \%$ of their study population had previous experience of Traumatic Dental Injury (TDI) which had affected positively their knowledge of TDI management. In contrast, Chan et al ${ }^{4}$, Mohandas et a ${ }^{21}$ and C. Blakytny et $\mathrm{a}^{28}$ have not found any correlation between previous TDI experience and TDI management knowledge.

\section{REFERENCES}

1. Subramaniam R, Mittal $S$, HiregoudarM, Mohandas U, Sakeenabi B, Prashant GM. Knowledge of upperprimary and secondary school physical education instructors inDavangere city, India, about emergency management of dental trauma.JEduc Ethics Dent 2011;1:18-23.

2. Rao A. Principles and practice of pedodontics. $3^{\text {rd }}$ ed.New Delhi( India): Jaypee Brothers Medical Publishers (P) Ltd. 2012. Chapter 9, Trauma and its management; p.310-333.

3. McDonald RE, Avery DR and Dean JA. Management of trauma to the teeth and supporting tissues. In: McDonald RE and Avery DR (Eds.) Dentistry for the Child and Adolescent ( $8^{\text {th }}$ Ed). 2004. Mosby. St. Louis. 453-503.
Mouthguards are designed to protect teeth and intraoral soft tissues from injuries. The American Dental Association recommends properly fitted mouth guards for a variety of sports and recreational activities which predispose the participants to oral injuries ${ }^{32}$. In our study, two hundred and forty eight (58.7\%) had never heard of mouth guard while only $37.7 \%$ thought it could prevent injury to the tooth. In a study done by Karande $\mathrm{N}$ et al, only $23 \%$ of participants knew about mouth guard even after lectures given to them ${ }^{33}$. On questioning them about where they would take on any dental emergency, $50.5 \%$ of teachers preferred nearest hospital on foot or by any transport while only $32.3 \%$ would like to take to a dentist. This shows an immediate need for awareness among the teachers. This study also had some limitations. The teachers had to recall their first aid training and also the number of students suffering from dental trauma, so possibilities of recall bias can be there as the exact number becomes difficult to remember. As study is focused on Bhaktapur, the findings cannot be generalized to other places of Nepal.

\section{CONCLUSION}

Knowledge of the school teachers in Bhaktapur was seen to be inadequate for emergency management of fracture and avulsed tooth. Their educational background, first aid training, previous information on dental trauma and previous TDI experience in their students was only seen effective for managing displacement of tooth. As Nepal is a developing country, education system is needed to be improvised by including special training on emergency management of dental injuries for school teachers. This significantly increases the likelihood of a positive treatment outcome.

4. Chan AW, Wong TK, Cheung GS. Lay knowledge of physical education teachers about the emergency management of dental trauma in Hong Kong. Dent Traumatol 2001; 17: 77-85.

5. Ravn JJ. Dental injuiries in Copenhagen school children,school years 1967-1972. Community Dent Oral Epidemiol 1974; 2: 231-45.

6. Baghdady VS, Ghose IJ, Alwash R. Traumatised anterior teeth as related to their cause and place. Community Dent Oral Epidemiol 1981; 9: 91-3.

7. Garcia-godoy F, Sanchez R, Sanchez JR. Trauamtic dental injuries as in a sample of Dominician schoolchildren. Community Dent Oral Epidemiol 1981; 9: 193-7.

8. Davis GT, Knott SC. Dental trauma in Australia. Aust Dent J; 1984: 29: 217-21. 
9. Stockwell AJ. Incidence of dental trauma in the Western Australian School Service. Community Dent Oral Epidemiol 1988; 16: 294-8.

10. Glendour $U$, Andersson L. public health aspects of oral diseases and disorders; dental trauma. In: Pine C, Harris R, editors. Community oral health. London : Quintessence 2007; 203-14.

11. Glendour U, Halling A, Andersson L. Eilert-Petersson E. Incidence of traumatic tooth injuiries in children and adolescents in the country of Vastmanl and, Sweden. Swed Dent J 1996;20:15-28.

12. Petersson EE, Andersson L, Sorenson S. Traumatic oral vs non -oral injuries. Swed Dent J1997; 21: 5568.

13. Ministry of Education: A Glimpse 2010. Kathmandu:Ministry of Education of Nepal. Monitoring,Evaluation \& Supervision Division;Asar 2067 (June 2010). 169. p 14.

14. Vidyalayastariya Nepal koShaikschhikTathyank 2057 (2000). (Department of Education, Bhaktapur).

15. Timsina TP. (2008). School effectiveness with preference to the public and private schools in Nepal: an unpublished M phil. Dissertation. School of Education, Kathmandu University: Nepal.

16. Al-Jundi SH, Al-Waeili H, Khairalah K. Knowledge and attitude of Jordanian School health teachers with regards to emergency management of dental trauma. Dent Traumatol 2005 Aug; 21(4): 183-7.

17. Newman L, Crawford PJM. Dental injuries "first aid" knowledge of Southampton teachers of physical education.Endod Dent Traumatol 1991; 7: 255-8.

18. Stokes AN, Anderson HK, Cowan TM. Lay and professional knowledge of methods of emergency management of avulsed teeth. Endod Dent Traumatol 1992; 8: 160-2.

19. Sae-Lim V, Lim LP. Dental trauma management awareness of Singapore preschool teachers. Dent Traumatol 2001; 17: 71-6.

20. Al-Asfour A, Andersson L, Al-Jame Q. School teachers' knowledge of tooth avulsion and dental first aid before and after receiving information about avulsed teeth and replantation. Dent Traumatol 2008; 24: 43-9.

21. Mohandas U, Chandan GD. Knowledge, attitude and practice in emergency management of dental injuiry among physical education teachers: A survey in Bangalore urban schools.J Indian SocPedod Prevent Dent 2009; 27(4): 242-8.

22. Al-Obaida M. Knowledge and management of traumatic dental injuiries in a group of Saudi primary schools teachers. Dent Traumatol 2010; 26: 338-41.

23. Prasanna S, Giriraju A, Narayan NL. Knowledge and attitude of primary school teachers toward tooth avulsion and dental first aid in Davangere city: a cross-sectional survey. International Journal of Clinical Pediatric Dentistry 2011; 4(3): 203-6.

24. Arikan V, Sonmez H. Knowledge level of primary school teachers regarding traumatic dental injuries and their emergency management before and after receiving an informative leaflet. Dent Traumatol 2012; 28(2): 101-7.

25. Lwanga SK, Lemeshow S. Sample size determination in health studies: a practical manual. Geneva: World Health Organization; 1991.

26. Feldens EG, Feldens CA, Kramer PF, da Silva KG, Munari CC, Brei VA. Understanding school teacher's knowledge regarding dental trauma: a basis for future interventions. Dent Traumatol 2010;26: 15863.

27. MesgarzadehAH,Shahamfar M, Hefzollesan A. Evaluating knowledge and attitude of elementary school teachers on emergency management of traumatic dental injuries: a study in an Iranian urban area. Oral Health Prev Dent 2009; 7: 297-308.

28. Blakytny C, Surbuts C, Thomas A, Hunter ML. Avulsed permanent incisors:knowledge and attitude of primary school teachers with regard to emergency management. Int J Paediatr Dent 2001; 11: 327-32.

29. McIntyre JD, Lee JY, Trope M, Vann WF Jr. Elementary school staff knowledge about dental injuries. Dent Traumatol 2008; 24: 289-98.

30. Andreasen JO, Andreasen FM. Textbook and color atlas of traumatic injuries to the teeth. $3^{\text {rd }}$ ed. Copenhagen: Munksgaard; 1994.

31. Andersson L, Al-Asfour A, Al-Jame Q. knowledge of first-aid measures of avulsion and replantation of teeth: an interview of 221 Kuwaiti schoolchildren. Dent Traumatol 2006; 22: 57-65.

32. Muthu MS, SivakumarN. Pediatric Dentistry. Principles and Practice. $2^{\text {nd }}$ ed. Elsevier: India. 2011. $259 \mathrm{p}$.

33. Karande N, Shah P, Bhatia M, Lakade L, Bijle MN, Arora N, Bhalla M. Assessment of awareness amongst school teachers regarding prevention and emergency management of dentoalveolar traumatic injuries in school children in Pune City, before and 3 months after dental educational program. J Contemp Dent Pract. 2012 Nov 1;13(6):873-77. 